\title{
EXPORT INTENSITY AND THE COMPETITIVE INTELLIGENCE OF EXPorting COMPanies: EVIDENCE From South Africa ${ }^{1}$
}

\author{
Ludo Cuyvers and Michel Dumont \\ Department International Trade, University of Antwerp \\ Wilma Viviers \\ School of Economics, North-West University \\ Patrick de Pelsmacker \\ Business School, University of Antwerp \\ Marié-Luce Muller \\ IBIS Business and Information Systems \\ Marc Jegers \\ Department of Economics, Free University Brussels \\ Andrea Saayman \\ School of Economics, North-West University
}

\begin{abstract}
The present paper investigates the relationship between Competitive Intelligence $(\mathrm{Cl})$ factors, characteristics, information sources, needs, requirements and the export intensity of exporting companies in South Africa. We establish whether there are significant differences between firms, grouped according to export intensity with respect to awareness, use, information sources and attitude towards $\mathrm{Cl}$ activities.

A questionnaire was developed and sent to exporting firms, resulting in a usable sample of 309 South African respondents. These firms are grouped according to export intensity, and $\mathrm{Cl}$ practices between groups are compared.

The results show that export intensive firms appear to be more aware and supportive of $\mathrm{Cl}$ activities than less export intensive firms.
\end{abstract}

JEL L86, O32

\section{1}

\section{Introduction}

Competitive Intelligence (CI) is the component of Business Intelligence aimed at gaining strategic advantage (Porter, 1980). Therefore, it includes competitor intelligence as well as intelligence collected on customers, suppliers, technologies, environments, or potential business relationships (Guyton, 1962; Fair, 1966; Grabowski, 1987; Gilad, 1989).

A review of the literature related to competitive intelligence suggests that competitive intelligence is a marketing research discipline focused on gathering information on the competition (Schollhammer, 1994; Agarwal, 1993).

However, a broader examination shows that intelligence is not only about monitoring competition but rather monitoring the entire business environment to capture all of the multiple functions within the competitive process. Gilad (1996) stated that the objective of intelligence is "being able to predict competitors' moves, customers' moves, government moves and so forth." In the broadest sense, intelligence (including the collection, analysis, and dissemination of knowledge) is the process of reducing managerial decision uncertainty. 
Companies that are active as exporters in the international market evidently have other information and CI needs than local firms. The business environment (e.g. nature of competition, the distribution systems) differs from country to country, which must have an impact on the information system and CI requirements. In addition, the degree of export reliance of companies - or the degree of international commitment in the export business of the company - can be expected to influence the intensity of use that is made of internal and external information, the structure of the company's information system, and the nature of the CI practices.

Quite evidently, the frequency and efficiency of the use that is made of information sources and $\mathrm{CI}$, the characteristics of the evolving CI systems, the learning processes involved, etc. will influence the success in the international market and therefore the export intensity of the company's activities (Johanson \& Vahlne, 1977; Walters \& Samiee, 1990; Toften \& Olsen, 2003; Leonidou \& Theodosiou, 2004).

The relationship between the degree of export orientation of companies and the various characteristics of their information systems and CI practices and needs is therefore likely to be one of mutual causation.

Since the mid-1970s, a good deal of research has focused on the development of firms' exporting activities. Two main streams of research concerning the export development process are readily apparent. The dominant stream posits a "stages" model of export development, ranging from "uninterested in exporting" to "full commitment" to international markets, using a range of differing criteria. Firms are conceptualised as growing incrementally along a learning curve, moving from one export stage to the next on their way to becoming fullyfledged, committed exporters. It is generally assumed that the process is evolutionary in nature (Bilkey \& Tesar, 1977; Chisnall, 1977; Wiedersheim-Paul, Olson \& Welch, 1978; Cavusgil, 1980). The second stream of research differs in one important facet. Unlike the stages models, where greater involvement in exporting is viewed as an evolutionary and incremental process, this work does not assume incremental development (Samiee \& Walters, 1991; Rao \& Naidu, 1992; Katsikeas \& Dalgic, 1995). A central theme in this conceptualisation is that firms do not necessarily incrementally evolve into more committed exporters over time. Some firms have a proactive attitude toward international markets right from their inception due to a range of factors that include the background, training and experience of key personnel. Other firms follow the incremental path and progress to regular export involvement more gradually. Sporadic exporters, on the other hand, exhibit less interest in exporting, maintaining a steady state of low-level export activity for long periods. This reflects that priorities and circumstances of exporting firms often do not change much over time. As a result, there is no inherent momentum for export development.

Most scholars agree that the internationalisation process of companies evolves gradually (Chisnall, 1977; Cavusgil, 1980; WiedersheimPaul, Olson \& Welch, 1978) and that as they gain international experience, their management may develop higher expectations, evolve and adopt better suited internationalisation policies and strategies, and adapt organisational structures and procedures. One of these structures is the company CI system.

In this paper, we will statistically explore the relationship between CI factors and characteristics, as well as information sources, needs and requirements, on the one hand, and the export intensity of exporting companies in South Africa, on the other hand.

In the next section, the empirical literature is reviewed. This review will not deal with the literature on information needs and practices of exporting companies (McAuley, 1993), but fully concentrate on whether these needs and practices differ among the exporting companies categorised according to four export intensity levels (defined as the share of exports in company sales).

In the third section the data collection phase of the present research is briefly outlined, after which the results of the empirical analysis are discussed. Conclusions, implications and suggestions for further research are provided in the final section. 
2

\section{Review of the literature}

In spite of the fact that many standard international marketing research textbooks provide suggestions and even prescriptions as to the type of marketing research information needed, the issue that is relatively under-covered is whether exporting companies are using this information, or whether the types of information needed tend to change in line with the degree of internationalisation of the companies.

Research has revealed that exporters conduct a more intensive search for information than non-exporters, attach more importance to market knowledge, and are more likely to conduct their own market research (Burton \& Schlegelmilch, 1987), but the issue we deal with in this paper is rather whether information factors and CI systems differ according to the export intensity of exporters.

Cavusgil distinguished three categories of exporting firms (experimental, active, committed) and then endeavoured to show, based on statistical analysis, differences between these categories. His data set related to exporting manufacturers from Wisconsin and Illinois. One of the many aspects he investigated is differences between the three groups of exporters and their foreign market research practices. It is shown that as companies progress through their internationalisation process, they will commit more financial and managerial resources to market research, reflecting the need for a more thorough analysis and assessment of potential in foreign markets. Also the nature of the information and data sources required and used will change from general market information for the experimental exporters, to industry/business publications and trade show contacts for both the experimental and active exporters. When exporters become committed, they will find it necessary to develop an internal information system for market research (Cavusgil, 1984a). In another study, Cavusgil found that more internationalised companies are using a wider variety of data sources, without, however, offering a specific definition of information type (Cavusgil, 1984b).
In another pioneering study, Koh, Chow and Smittivate (1993) looked into the practices of international marketing research of Thai exporters in two industrial sectors (canned food and electronics, electrical appliances and parts). Again, one of the aspects researched is the degree of internationalisation of the companies and international marketing research practices. The authors found no significant differences between export experience or export intensity (measured by the percentage of export sales to total sales, i.e. less than 50 per cent and 50 per cent or more, respectively) and the perceived usefulness of conducting international marketing research. A similar absence of relationship is reported between export experience and the frequency of conducting such research, but export intensity seems to have an impact on the frequency of focusing on issues such as socio-cultural factors, the estimation of market size, competition, pricing, product features and consumer preferences (Koh, Chow \& Smittivate, 1993).

The results obtained by Hart, Webb and Jones (1994) on British small and medium sized enterprises, showed no statistically significant differences in the type of information, the market research activities and the use of market research, between companies exporting less than 12 years and these with more than 12 years experience. They, however, state that it is possible that 12 years' export experience is not enough to discriminate marketing research activities.

Using survey data from three Ohio industry groups (non-electrical machinery, electrical and electronic machinery, and measuring, analysing and controlling instruments), Lim, Sharkey and Kim (1996) found a number of significant differences between high-involvement exporters and low-involvement exporters, particularly related to the way information was gathered from primary and secondary sources, and the extent to which they conduct marketing research. Statistical differences were also found relating to the monitoring of competitors' performance and their export intentions. A multiple regression analysis resulted in a positive relationship between export intensity (they used the term "export success") and four variables: information 
gathering from secondary sources, conducting market research, information gathering about competitors' involvement in exporting, and information on product changes.

In another study, Leonidou (1997) calculated whether high and low export intensities (more or less than 50 per cent share of exports in sales), as well as export experience, of exporters in Cyprus coincide with differences in some factors relating to information. Only three information factors showed a statistically significant positive relationship with export intensity: information on foreign market preferences, the company's market position and issues pertaining to promotional activity abroad. The impact of export experience on information type preferences was minimal.

In their review of 27 studies on the export marketing information system, Leonidou and Theodosiou (2004) conclude that current research too is a-theoretic, fragmented and inconsistent. They distinguish four aspects of export information behaviour: determination, acquisition, dissemination and utilisation. None of the studies considered, appear to examine all four dimensions of export information behaviour and as a result do not provide a comprehensive analysis of the characteristics, sources, needs and phases/constructs of competitive intelligence.

Most empirical work is restricted to exporters of a given country/industry and many studies are based on small samples (less than 150 firms). Moreover, as a number of these studies use non-probabilistic sampling designs, Leonidou and Theodosiou (2004) question their representativeness.

With respect to antecedent factors (company size, industry, export experience, expansion strategy and distance) empirical work does not seem to provide unambiguous conclusions, though smaller firms seem to use less expensive, easily accessible and more informal information sources than large firms.

Leonidou and Theodosiou (2004) found six studies in which export experience is used as a potential discriminator of export information behaviour. They conclude that overall these studies failed to find substantial differences in information requirements between new and established exporters although in the earliest study by Ursic and Czintoka (1984) newer exporters are found to be more aggressive in seeking export information, and McAuley (1993) found that the more experienced exporting firms use fewer information providers.

Studies examining the export information behaviour of exporters versus non-exporters found that although exporters more actively search for information, differences between exporters and non-exporters were not significant with respect to most dimensions.

Leonidou and Theodosiou (2004) point out that studies in which the information requested is linked to export intensity (i.e. proportion of export sales to total sales) reveal few significant results. In addition to the aforementioned studies by Koh, Chow and Smittivate (1993) and Leonidou (1997), they refer to Walters (1983) who found that export intensive firms made more use of export agents, statistical agencies, departments of commerce and company executives, and to Benito, Solberg and Welch (1993) who report greater use of formal procedures and service people, but less use of international journals (newspapers), management consultants and sales representatives by firms that were intensifying their export strategy.

Leonidou and Theodosiou (2004) concluded their review of the literature on export information by stating that research could be improved by e.g. a cross-cultural approach, more representative samples and a more comprehensive operationalisation and measurement of constructs. By considering all dimensions of the CI process and the link with antecedent factors (with a focus on export intensity), using relatively large firm sample we believe to provide some contribution to the existing literature.

\section{3}

\section{Data collection}

The data used in this paper come from a survey, on competitive intelligence practices, that was sent to exporting firms in South Africa. Starting from earlier descriptive research (Calof \& Breakspear, 1999; Viviers, Saayman, Muller \& Calof, 2002) a questionnaire was developed and pre-tested. It 
contained, among others, 39 CI-related questions, to be answered on a 5-point Likert scale. The Likert scale questions were divided into two sections. In the first section (questions 4 to 20), the respondents had to indicate to which degree they agreed or disagreed with the statement (1 strongly disagree and 5 strongly agree). In the second part (questions 21 to 42) the respondents had to indicate to what extent (never or always) they implement a certain action. In this section, 1 equals never and 5 equals always. Additionally, a limited number of general questions pertaining to the firm were asked (activity, size, percentage of sales exported).

The questionnaire was structured to test all theoretical Competitive Intelligence dimensions: planning and focus; collection; analysis; communication; process and structure; and awareness and culture. Based on the data collected through the survey, Saayman et al. (2004) performed an explanatory and confirmatory factor analysis to identify (and test the validity of) factors related to different aspects of competitive intelligence as derived from previous theoretical work. Five dimensions of CI were identified empirically:

1. process and structure

2. planning, focus and collection

3. data analysis and quality control

4. culture and awareness

5. skills development

In addition the survey contained questions with regard to the number of years of $\mathrm{CI}$ experience the firm has, the number of employees (fulland part-time) performing CI tasks, the time devoted to different $\mathrm{CI}$ activities, whether the firm has a separate CI department or not and who holds the main responsibility for CI within the firm, and the company's information needs and sources. ${ }^{2}$

The data of exporting companies was gathered from two sources, namely (i) the Kompass Southern African database (from Reed Business Southern Africa) and (ii) the directors/CEO's of the respective Export Council (supported by Trade and Industry Southern Africa). A total of 321 responses was received, representing a response rate of 8.11 per cent. All companies that did not complete at least 70 per cent of the questions were removed from the analysis. This left us with a useful sample of 309 South African companies.

Although no argumentation can be put forward against potential non-response bias, as there is no South African database of exporters according to size, sector or export intensity, it can be stated that at least some characteristics of the economy are reflected in the sample. The exporters surveyed are mainly in the manufacturing sector, which is consistent with the main export sector of South Africa, while the low export intensity of South African exporters is typical of the broader export population as is evident in a study by Viviers and Calof (1995).

Traditionally, two measures of export performance, i.e. export proportion of sales ("export intensity") and average size of export transactions are used to assess export development and performance. In a previous study, four stages were used: no export sales, export intensity 1-24 per cent, intensity of 25-49 per cent and intensity greater than 50 per cent (Viviers, Kroon \& Calof, 1996). Due to an insufficient number of observations with export intensity above 75 per cent they were not able to use a finer categorisation. In the present research exporters were asked the share of exports in the company sales based on the following four groups:

- $1-24 \%(\mathrm{G} 1)$

- $25-49 \%(\mathrm{G} 2)$

- $50-74 \%(\mathrm{G} \mathrm{3})$

- $75-100 \%$ (G 4)

The reason for not including the "no export sales" group is that the population of companies in the present research only consists of exporting companies. We expect that export intensity is having an impact on both the time devoted to CI, and the content of the $\mathrm{CI}$ activities, i.e., exporting companies with a higher share of exports in their sales figure, will devote more time to CI, and we also expect the type of CI that is most relevant to change with export intensity. However, the distance for South African exporters to the major markets that are dispersed worldwide, and therefore, the relative ease of organising the exporting company's CI can be expected to influence this expected impact. 


\section{4}

\section{Export intensity and competitive intelligence}

\subsection{Export intensity}

As stated earlier, using the answers of the Competitive Intelligence survey for exporters of South Africa, four categories of export intensity (exports/ sales) can be distinguished. In Table 1 we report the frequencies of the four groups of export intensity in the South African sample.

It is evident that almost 40 per cent of South African exporters in the sample have an export intensity of more than 50 per cent, with most firms falling into the low export intensity group (1-24 per cent).

Table 1

Frequencies of export intensity for the South African sample

\begin{tabular}{|c|c|}
\hline Export Intensity & South Africa \\
\hline $1-24 \%$ & $43 \%$ \\
\hline $25-49 \%$ & $17 \%$ \\
\hline $50-74 \%$ & $18 \%$ \\
\hline $75-100 \%$ & $22 \%$ \\
\hline$N$ & 303 \\
\hline
\end{tabular}

\subsection{CI experience}

Figure 1 shows the share of firms in each of the four export intensity groups with 0 years, 1-5 years, 5-10 years and more than 10 years of experience in CI activities. South African firms with export intensity between 25 per cent and 74 per cent have more $\mathrm{CI}$ experience than firms with less than 25 per cent export intensity, and more surprisingly also more experience than firms with more than 75 per cent export intensity. Moreover, a Chi-square test indicates that these differences are significant.
Figure 2 shows the share of firms in each of the four export intensity groups with $0,1,2$ or more than 2 , respectively full-time and parttime employees engaged in CI activities. There is apparently no clear-cut relationship between export intensity and the number of employees performing CI tasks. None of the differences in terms of the number of employees engaged in CI activities is found to be significant (Chisquare test).

\section{Figure 1}

Number of years $\mathrm{Cl}$ experience broken down by export intensity

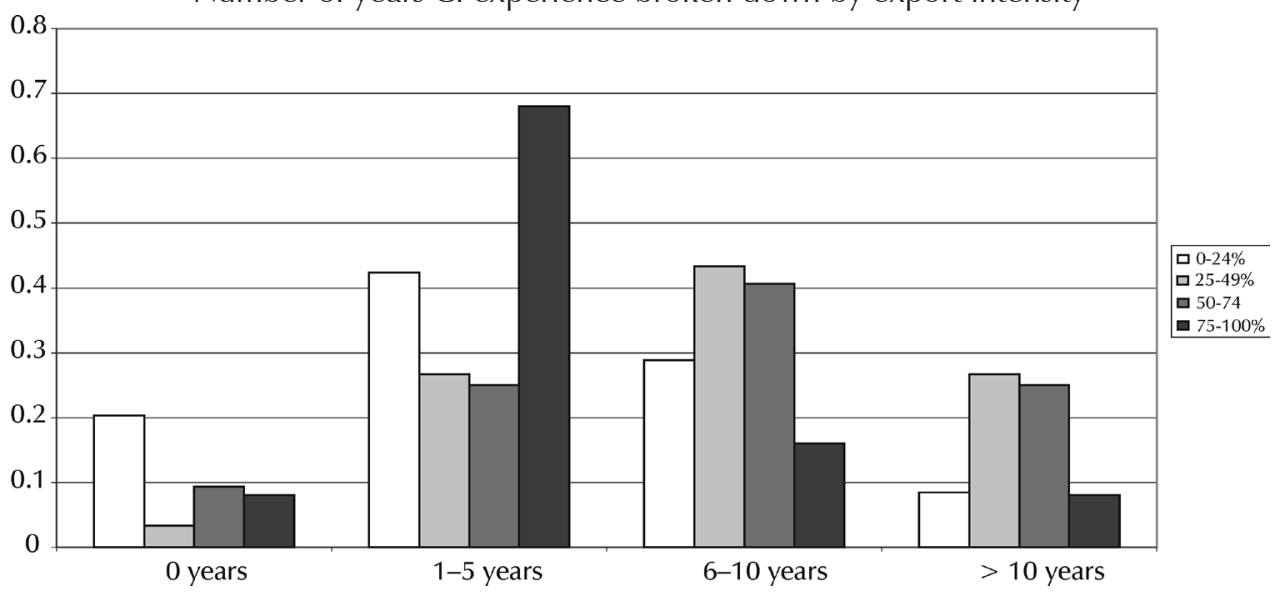




\section{Figure 2}

Number of full-time and part-time $\mathrm{Cl}$ employees

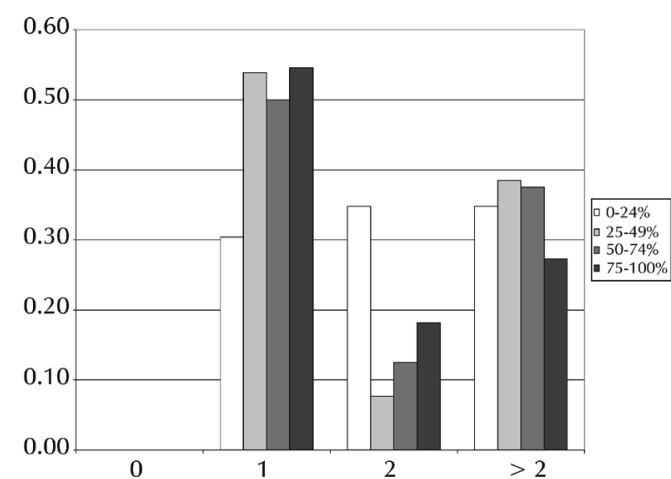

We will now assess whether significant differences exist between the four groups of respondents with regard to competitive intelligence activities.

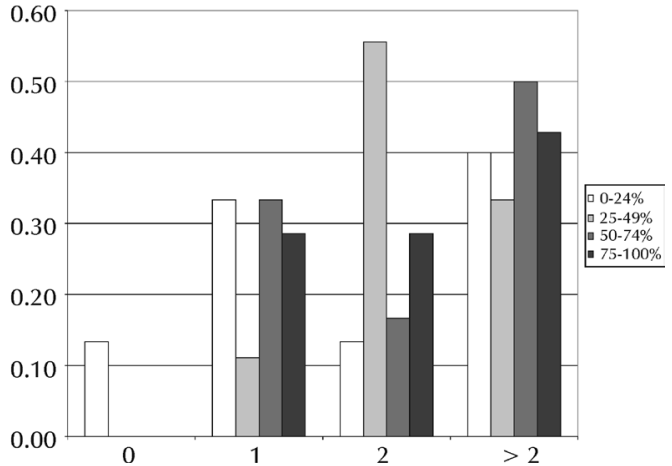

\subsection{CI dimensions}

Table 2 shows the five constructs that were previously identified (Saayman et al., 2004), reflecting different dimensions of CI, as well as the questions of the questionnaire to which they refer. For each factor the average score over the variables loaded onto them has been considered to assess differences between the four export intensity groups.

\section{Table 2}

Items in the five-factor model

\begin{tabular}{|l|l|}
\hline Factor & Items \\
\hline Process \& structure & $\begin{array}{l}\text { Our intelligence findings are widely distributed within the firm (Q13) } \\
\text { We maintain a comprehensive map or inventory of internal information and } \\
\text { knowledge (Q14) } \\
\text { There is a central co-ordination point for receiving information (Q15) } \\
\text { Our firm maintains a central record of reliable sources of information (Q20) }\end{array}$ \\
\hline $\begin{array}{l}\text { Planning, focus \& } \\
\text { collection }\end{array}$ & $\begin{array}{l}\text { Our firm produces assessments that address several possible outcomes of our } \\
\text { competitors' actions that might be threats or opportunities for our firm (Q26) } \\
\text { We meet with executives to identify their intelligence needs (Q31) } \\
\text { We train/prepare our employees before they go to trade shows, exhibitions, } \\
\text { conventions, etc. about what information they should look for (Q37) } \\
\text { Results of exit interviews/job interviews are used in our intelligence system (Q38) }\end{array}$ \\
\hline $\begin{array}{l}\text { Data analysis \& } \\
\text { quality control }\end{array}$ & $\begin{array}{l}\text { Our company develops profiles on emerging technologies to better understand their } \\
\text { characteristics, potential application and market advantages (Q33) } \\
\text { Key decision-makers are surveyed/interviewed to verify that the intelligence } \\
\text { products produced for them satisfy their needs (Q35) } \\
\text { All information is checked for accuracy and validated by at least one source (Q36) } \\
\text { We evaluate the reliability of our sources of information (e.g. persons, publications, } \\
\text { internet) (Q41) }\end{array}$ \\
\hline
\end{tabular}




\begin{tabular}{|l|l|}
\hline Culture \& awareness & $\begin{array}{l}\text { Our firm recognises competitive intelligence as a legitimate and necessary activity } \\
\text { for business (Q5) } \\
\text { Senior management supports intelligence findings (Q8) } \\
\text { Competitive intelligence can be used to create a competitive advantage (Q9) }\end{array}$ \\
\hline Skills development & $\begin{array}{l}\text { Most employees understand what competitive intelligence is (Q7) } \\
\text { Our firm has incentives to encourage employees to report their competitive } \\
\text { observations and information (Q10) } \\
\text { We make competitive intelligence training (e.g. collection and analysis techniques) } \\
\text { available to our employees (Q16) }\end{array}$ \\
\hline
\end{tabular}

Source: Saayman et al. (2004)

Figure 3 shows the average response regarding the five factors for the four respective export intensity groups in the sample of South African firms. Using visual evaluation, the differences appear to not be substantial.

Figure 3

Average scores $\mathrm{Cl}$ dimensions

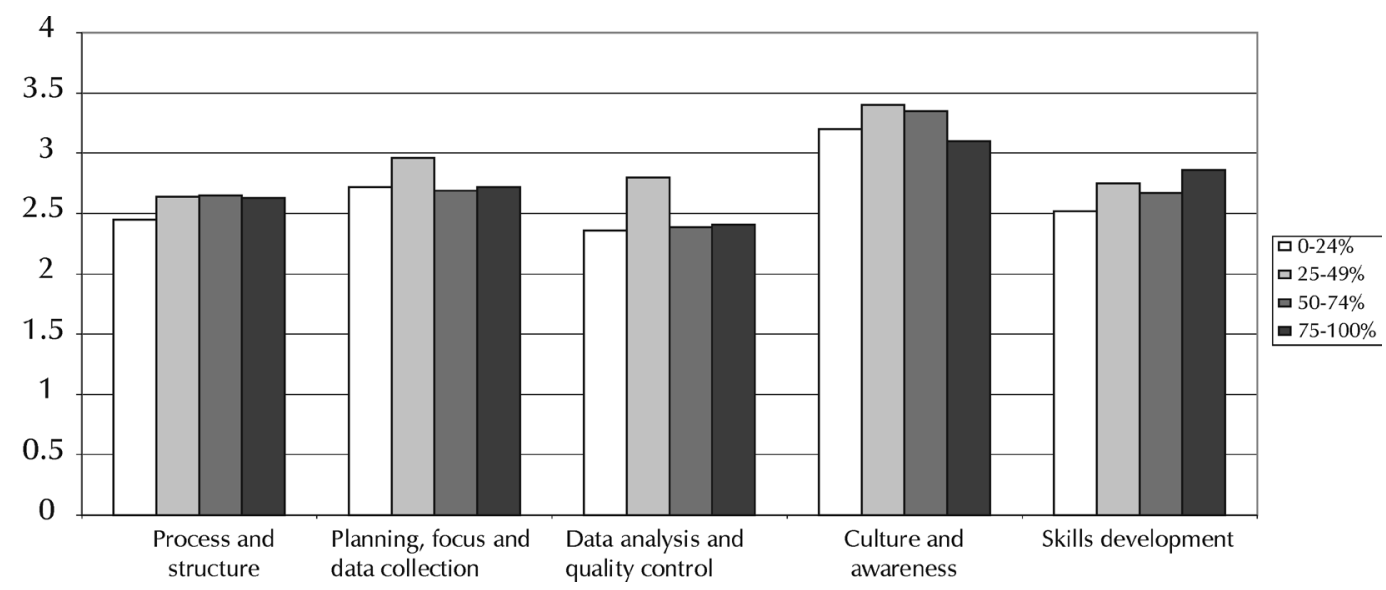

For a statistical assessment of the differences between the four groups, we performed an analysis of variance (ANOVA) in SPSS, which permits to test the statistical significance of differences in average responses between groups. The results of the ANOVA are reported in Table 3 . The F value tests the null hypothesis that all group means are equal, i.e. rejection implies that the means differ significantly.
The Brown-Forsythe statistic also tests the hypothesis that means do not differ. This statistic however, does not depend on the assumption that variances are equal. Results of a Levene statistic $^{3}$ show that for some factors the null hypothesis of equal variances is rejected. For the South African firms grouped according to export intensity, there is no factor for which the average responses appear to differ significantly. 
Table 3

Results ANOVA

\begin{tabular}{|l|l|c|c|c|}
\hline & & SumS (df) & F & BF \\
\hline \multirow{3}{*}{ F1 } & Between & $5.1(3)$ & & \\
& Within & $301.0(292)$ & 1.66 & 1.57 \\
& Total & $306.2(295)$ & $(0.177)$ & $(0.199)$ \\
\hline \multirow{3}{*}{ F2 } & Between & $2.7(3)$ & & \\
& Within & $249.0(289)$ & 1.03 & 1.07 \\
& Total & $251.6(292)$ & $(0.378)$ & $(0.364)$ \\
\hline \multirow{3}{*}{ F3 } & Between & $3.8(3)$ & & 1.26 \\
& Within & $288.9(292)$ & 1.27 & $(0.290)$ \\
\hline \multirow{4}{*}{ F4 } & Total & $292.7(295)$ & $(0.285)$ & 1.67 \\
& Between & $4.9(3)$ & & $(0.198)$ \\
\hline \multirow{3}{*}{ F5 } & Within & $279.8(295)$ & 1.73 & 1.24 \\
& Total & $284.8(298)$ & $(0.161)$ & $(0.295)$ \\
\hline
\end{tabular}

Note: SumS (df) - sum of squares (degrees of freedom), F - F statistic (p-value in brackets),

BF- Brown - Forsythe statistic. ${ }^{*}: \mathrm{p}<0.10,^{* *}: \mathrm{p}<0.05$ and $^{* * *}: \mathrm{p}<0.01$.

To check whether the results of the analysis of variance are not merely reflecting differences in company size or economic sectors, we performed the same analysis selecting different sectors and company size groups as far as the number of observations made this possible. Overall the previous results seem robust although in some cases differences in response between the four export intensity groups are found to be significant for more factors. In this sample of South African firms with more than 200 employees, differences between the four groups are now significant for all five factors. The results of these analyses are not reported but available upon request.

\subsection{CI activities}

Respondents were also asked to rate the importance of different types of CI activities. In Table 4 the statistically significant differences - between the four groups of export intensity - in the share of time devoted to five aspects of CI are reported. Firms of group $\mathrm{G} 2$ devote more time to data collection than firms with export intensity exceeding 50 per cent ( $\mathrm{G} 3$ and $\mathrm{G} 4$ ), whereas group $\mathrm{G} 4$, the group of most export intensive firms, devotes significantly more time to analysis, interpretation and evaluation than group G 2 .

Table 4

Share of time (\% of total time) devoted to specific $\mathrm{Cl}$ activities

\begin{tabular}{|l|l|}
\hline \multicolumn{2}{|l|}{ South Africa } \\
\hline Data collection & G2 $(58.00)>$ G3 $(39.23)^{*}$ \\
& G2 (58.00) > G4 (31.92)** \\
Analysis and interpretation & G4 (27.69) $>$ G2 (17.67)* \\
Evaluation & G4 (15.00) $>$ G2 (8.39)* \\
Recommendations & \\
\hline
\end{tabular}

Note: ${ }^{*}$ Significant at $5 \%,{ }^{*}$ significant at $10 \%$ level. 


\subsection{Information sources}

For a number of information sources the respondents had to indicate whether they found them unimportant, important or very important. In Table 5 the differences in percentage of firms that consider a given type of $\mathrm{CI}$ information as very important are reported for the four groups. It is found that the most export intensive firms consider information on how to penetrate world markets to be significantly more important, than less export intensive firms.

\section{Table 5}

Percentage of firms per export intensity category that consider a type of $\mathrm{Cl}$ information to be very important (top 3 of important types shaded)

\begin{tabular}{|c|c|c|c|c|}
\hline & $1-24 \%$ & $25-49 \%$ & $50-74 \%$ & $75-100 \%$ \\
\hline How to penetrate on world markets & $60.0 \% *$ & $29.4 \% *$ & $66.7 \% *$ & $89.3 \% *$ \\
\hline Profiles of potential customers & $54.3 \%$ & $43.8 \%$ & $63.2 \%$ & $71.4 \%$ \\
\hline Opportunities in new markets & $80.6 \%$ & $81.3 \%$ & $84.2 \%$ & $89.3 \%$ \\
\hline $\begin{array}{l}\text { Reputation and activities of } \\
\text { competitors }\end{array}$ & $37.1 \%^{\circ}$ & $37.5 \%{ }^{\circ}$ & $63.2 \%^{\circ}$ & $60.7 \%^{\circ}$ \\
\hline Potential partners or agents & $77.1 \%$ & $81.3 \%$ & $84.2 \%$ & $82.1 \%$ \\
\hline Distribution channels & $51.3 \%$ & $56.3 \%$ & $78.9 \%$ & $60.7 \%$ \\
\hline Culture & $17.1 \% *$ & $18.8 \% *$ & $52.6 \% *$ & $64.3 \% *$ \\
\hline Political situation & $31.4 \%+$ & $18.8 \%+$ & $52.6 \%+$ & $57.1 \%+$ \\
\hline Statistical information about markets & $42.9 \%^{\circ}$ & $31.3 \%^{\circ}$ & $36.8 \%^{\circ}$ & $71.4 \%^{\circ}$ \\
\hline Regulations, barriers & $38.9 \% *$ & $31.3 \% *$ & $42.1 \% *$ & $70.4 \% *$ \\
\hline Trade fairs & $26.5 \%^{\circ}$ & $56.3 \%^{\circ}$ & $57.9 \%^{\circ}$ & $64.3 \%^{\circ}$ \\
\hline Exchange regulations & $34.3 \%^{\circ}$ & $25.0 \%^{\circ}$ & $55.6 \%^{\circ}$ & $66.7 \%^{\circ}$ \\
\hline
\end{tabular}

Note: Level of statistical significance of differences between the four groups $-^{\circ}: p<0.10,+: p<0.05$ and $*: p<0.01$.

Table 5 shows that there are significant differences between South African firms with various export intensities. The share of South African export intensive firms that regard information on culture, the political situation, and regulations and barriers as very important, significantly exceeds the share of less export intensive firms. This supports the notion that export-intensity has an impact on the frequency of focusing on issues such as socio-cultural factors, as suggested by Koh, Chow and Smittivate (1993).

Information on opportunities in new markets and potential partners or agents tops the list of important types of CI information for all firms, irrespective of their export intensity. This supports the finding of Leonidou (1997) as well of Hart, Webb and Jones (1994) that export experience has a minimal impact on information type preferences.

Yet, there are no significant differences regarding export intensity amongst the four groups as to the importance of different information sources (e.g. information of company staff, published information, internet, government organisations).

This finding contrasts somewhat with McAuley (1993) who found that more experienced exporters use fewer information providers, and with Benito, Solberg and Welch (1993), who found that more intensive exporters make less use of published (secondary) sources of information. 
5

\section{Conclusions, implications and suggestions for further research}

Using data from a competitive intelligence survey sent to South African exporting firms, we have tried to establish whether there are significant differences between firms, grouped according to export intensity, with respect to the awareness, use, information sources and attitude towards CI activities. To our knowledge, the present study is the first one to link the constructs of CI, the number of years in exports, the number of staff in CI, time devoted to CI activities as well as information needed for $\mathrm{CI}$ to export intensity.

Following the five constructs of CI that have been identified previously, we find that for South African exporting firms the average responses of the four groups do not seem do differ for any of the five factors that have been identified and verified as constructs of $\mathrm{CI}$ activities.

Our results have significant managerial implications for exporters of more and less export intensity alike. Recognising the value of $\mathrm{CI}$ as a strategic management instrument could enhance an exporter's competitiveness for various reasons: It gives management a more comprehensive and accurate picture of the competitive environment in the various markets the exporter is playing in. It could forewarn the exporter of impending threats and emerging opportunities such a new product opportunities. It can assist in strategic, long-term decision-making and it could be used for tactical, immediate decision-making.

As far as the relationship between CI factors and characteristics, information sources and information needs on the one hand and export intensity on the other hand is concerned, the research results show that export intensive companies value the importance of CI planning, CI structures and focusing on and collecting the right information as important.

The extent of CI activities seem to relate to the export intensity of firms in that the more export intensive firms are more experienced in CI. This is possibly explained by the increased and sustained need for better, faster and more accurate strategic and tactical decisions and the recognition that an effective CI capability could enhance such decisions. It was interesting to note that the most export intensive firms devoted most of their CI time on analysis, interpretation and evaluation. This is possibly due to the fact that there is an abundance of information available but that the real meaning of that information for a particular exporter is not easily discernable. South African exporters are also geographically and culturally further removed from their markets and this probably leads to less knowledge about the different export markets hence the increased need for CI.

In terms of CI sources, no significant differences are found between the various groups of export intensity. Abundant relevant information is available from various sources and the use (or not) of a variety of sources may not be directly related to the export intensity of companies. The competitive environment with its changing players, consumer preferences and changing regulatory and technological factors to name a few variables, is volatile. Sources of information and what they yield in terms of information, also change continuously and therefore it could be argued that export intensity and the importance of different information sources need not be directly related.

The extent to which exporters practice CI is related to their export intensity in many ways. CI could yield better knowledge of the market, better understanding of competitive factors, better understanding of where the exporter wants to go, measure of performance, products and services, existing customer base versus potential customer base and in general benchmarking against the best in the market. Better knowledge by means of continuous and focused CI activities could pave the way for increased export intensity.

Further research is however required in order to develop a thorough understanding of the use and benefits of CI relative to the export intensity of exporting companies and to clarify the ambiguities that arise from this research.

By and large, the results for South Africa confirm our hypothesis that both the quantity (time devoted to) and quality of the CI activities 
is larger/different for exporting companies with a higher export intensity (except for the group of companies with the highest export intensity). However, our results should be treated with the necessary caution, taking into account the relatively low response rate.

\section{Endnotes}

1 This paper stems from a research project financed under the Bilateral Agreement on Scientific and Technological Cooperation between the Republic of South Africa and the Flemish Community (Belgium). Global Insight South Africa is acknowledged for providing the service to enable us the electronic distribution and collection of the questionnaire in South Africa.

2 For full details on the questionnaire see Saayman et al. (2004).

3 Not reported but available upon request.

\section{References}

1 AGARWAL, S. (1993) "Influence of formalization on role stress, organizational commitment, and work alienation of salespersons: A cross-national comparison study", Journal of International Business Studies, 24: 715-740.

2 BENITO, G.R.G.; SOLBERG, C.A. \& WELCH, L.S. (1993) "An exploration of the information behaviour of Norwegian exporters", International Journal of InformationManagement,13: 274-286.

3 BILKEY, W.J. \& TESAR, G. (1977) "The export behaviour of smaller-sized Wisconsin manufacturing firms", Journal of International Business Studies, Spring/Summer: 193-198.

4 BURTON, F.N. \& SCHLEGELMILCH, B.B. (1987) "Profile analyses of non-exporters vs. exporters grouped by export involvement", Management International Review, 27: 38-49.

5 CALOF, J.L. \& BREAKSPEAR, A. (1999) "Competitive intelligence practices of Canadian technology firms", National Research Council/ Canadian Institute of Scientific and Technical Information.

6 CAVUSGIL, S.T. (1980) "On the internationalization process of firms", European Research, 8: 273-281.

7 CAVUSGIL, S.T. (1984a) "Differences among exporting firms based on their degree of internationalization", Journal of Business Research, 12: 205-207.

8 CAVUSGIL, S.T. (1984b) "International marketing research: insights into company practices”, Research in Marketing: 261-288.

9 CHISNALL, P.M. (1977) "Challenging opportunities of international marketing", European Research, 5: 12-34.

10 DE PELSMACKER, P.; MULLER, M.-L.; VIVIERS, W.; SAAYMAN, A.; CUYVERS, L. \& JEGERS, M. (2005) "Competitive intelligence practices of South African and Belgian exporters, Marketing Intelligence and Planning, 23: 606-620.

11 FAIR, W.R. (1966) "The corporate CIA a prediction of things to come", Management Science, 12: 489-503.

12 GILAD, B. (1989) "The role of organized competitive intelligence in corporate strategy", Columbia Journal of World Business, 24: 29-35.

13 GILAD, B. (1996) "Business Blindspots: Replacing Your Company's Entrenched and Outdated Myths, Beliefs and Assumptions with the Realities of Today's Markets, Infonortics: England.

14 GRABOWSKI, D.P. (1987) "Building an effective competitive intelligence system", Journal of Business and Industrial Marketing, 2: 39-44.

15 GUYTON, W.J. (1962) "A guide to gathering marketing intelligence", Industrial Marketing, March: 84-88.

16 HART, S.J.; WEBB, J.R. \& JONES, M.V. (1994) "Export marketing research and the effect of export experience in industrial SMEs", International Marketing Review, 11: 4-22.

17 HESTON, A.; SUMMERS, R. \& ATEN, B. (2003) "Penn world table Version 6.1" Center for International Comparisons at the University of Pennsylvania (CICUP), October 2002.

18 JOHANSON, J. \& VAHLNE, J.-V. (1977) “The internationalization process of the firm - A model of knowledge development and increasing foreign market commitments", Journal of International Business Studies, 8: 23-32.

19 KATSIKEAS, C.S. \& DALGIC, T. (1995) "Importing problems experienced by distributors: the importance of level of import development", Journal of International Marketing, 3(2): 51-70.

20 KOH, A.C.; CHOW, J. \& SMITTIVATE, S. (1993) "The practice of international marketing research by Thai exporters", Journal of Global Marketing, 7: 7-26.

21 LEONIDOU, L.C. (1997) "Finding the right information mix for the export manager", Long Range Planning, 30: 572-584.

22 LEONIDOU, L.C. \& THEODOSIOU, M. (2004) "The export marketing information system: An integration of the extant knowledge", Journal of World Business, 39: 12-36. 
23 LIM, J.S.; SHARKEY, T.W. \& KIM, K.I. (1996) "Competitive environmental scanning and export involvement: An initial inquiry", International Marketing Review, 13(1): 65-80.

24 MCAULEY, A. (1993) "The perceived usefulness of export information sources", European Journal of Marketing, 27: 52-64.

25 PORTER, M.E. (1980) Competitive Strategy: Techniques of Analyzing Industries and Competitors, The Free Press: New York.

26 RAO, T.R. \& NAIDU, G.M. (1992) "Are the stages of internationalization empirically supportable?", Journal of Global Marketing, 6(1/2): 147-70.

27 SAAYMAN, A.; DE PELSMACKER, P.; VIVIERS, W.; CUYVERS, L.; MULLER, M.L. \& JEGERS, M. (2004) "Export oriented competitive intelligence activities at the firmlevel: Testing and refining the underlying dimensions of the competitive intelligence process", Proceedings of the International Workshop on Competitive Intelligence, 8 October, University of Antwerp Management School.

28 SAMIEE, S. \& WALTERS, P.G.P. (1991) "Segmenting corporate exporting activities: sporadic versus regular exporters", Journal of the Academy of Marketing Science, 19(2): 93-104.

29 SCHOLLHAMMER, H. (1994) "Strategies and methodologies in international business and comparative management research", Management International Review, 34: 5-21.

30 TOFTEN, K. \& OLSEN, S.O. (2003) "Export market information use, organizational knowledge, and firm performance - A conceptual framework", InternationalMarketing Review, 20(1): 95-110.
31 UNCTAD (2003) Handbook of Statistics, New York/ Geneva: United Nations.

32 URSIC, M.L. \& CZINTOKA, M.R. (1984) "An experience curve explanation of export expansion", Journal of Business Research, 12: 159-168.

33 VIVIERS, W. \& CALOF, J.L. (1995) "The promotion of exports in South Africa”, Africa Insight, 25: 248-253.

34 VIVIERS, W.; KROON, J. \& CALOF, J.L. (1996) "The export behaviour of South African enterprises: Stages and attitudes towards exports", South African Journal of Business Management, 27: 34-41.

35 VIVIERS, W.; SAAYMAN, A.; MULLER, M.-L. \& CALOF, J.L. (2002) "Competitive intelligence practices: A South African study", South African Journal for Business Management, 33: 27-37.

36 VIVIERS, W., MULLER, M.-L; \& DU TOIT, A. (2005) "Competitive intelligence: An instrument to enhance South Africa's competitiveness", South African Journal of Economic and Management Sciences, 8: 246-254.

37 WALTERS, P.G.P. (1983) "Export information sources - A study of their usage and utility", International Marketing Review, Winter: 34-43.

38 WALTERS, P.G.P. \& SAMIEE, S. (1990) "A model for assessing performance in small US exporting firms", Entrepreneurship Theory and Practice, 15: 33-50.

39 WIEDERSHEIM-PAUL, F.; OLSON, H.C. \& WELCH, L.S. (1978) "Pre-export activity: The first step in internationalization", Journal of International Business Studies, 9: 47-58. 